Article

\title{
Matching of Nitrogen Enhancement and Photosynthetic Efficiency by Arbuscular Mycorrhiza in Maize (Zea mays L.) in Relation to Organic Fertilizer Type
}

\author{
Suravoot Yooyongwech ${ }^{1, *}$, Waraporn Threeprom ${ }^{1}$, Rujira Tisarum ${ }^{2}$, Thapanee Samphumphuang ${ }^{2}$, \\ Daonapa Chungloo ${ }^{2}$ and Suriyan Cha-um ${ }^{2}$ D \\ 1 School of Interdisciplinary Studies (Kanchanaburi Campus), Mahidol University, \\ Kanchanaburi 71150, Thailand; wthreeprom@yahoo.com \\ 2 National Center for Genetic Engineering and Biotechnology (BIOTEC), National Science and Technology \\ Development Agency (NSTDA), Pathum Thani 12120, Thailand; rujira.tis@biotec.or.th (R.T.); \\ thapanee@biotec.or.th (T.S.); daonapa.chu@biotec.or.th (D.C.); suriyanc@biotec.or.th (S.C.) \\ * Correspondence: suravoot@gmail.com
}

check for updates

Citation: Yooyongwech, S.; Threeprom, W.; Tisarum, R.; Samphumphuang, T.; Chungloo, D.; Cha-um, S. Matching of Nitrogen Enhancement and Photosynthetic Efficiency by Arbuscular Mycorrhiza in Maize (Zea mays L.) in Relation to Organic Fertilizer Type. Plants 2022, 11,369. https://doi.org/10.3390/ plants11030369

Academic Editors: Othmane Merah, Purushothaman Chirakkuzhyil Abhilash, Magdi T. Abdelhamid, Hailin Zhang and Bachar Zebib

Received: 26 December 2021

Accepted: 26 January 2022

Published: 29 January 2022

Publisher's Note: MDPI stays neutral with regard to jurisdictional claims in published maps and institutional affiliations.

Copyright: (C) 2022 by the authors. Licensee MDPI, Basel, Switzerland. This article is an open access article distributed under the terms and conditions of the Creative Commons Attribution (CC BY) license (https:// creativecommons.org/licenses/by/ $4.0 /)$.

\begin{abstract}
In the present study, Funneliformis mosseae (FM), Claroideoglomus etunicatum (CE), and Acaulospora foveata (AF) were inoculated to hybrid maize (Zea mays L. cv. CP888 ${ }^{\circledR}$ ). Upregulation of nitrogen levels were dependent on the type of mycorrhiza (AMF). Photosynthetic efficiency $\left(\mathrm{F}_{\mathrm{v}} / \mathrm{F}_{\mathrm{m}}\right)$ and water content in $\mathrm{FM}$ - and AF-inoculated plants were elevated, resulting in promotion of leaf area and shoot biomass. $\mathrm{N}$ content in the shoot and root tissues of the FM-inoculated plants increased by $21 \%$ and $30 \%$ over the control. A positive correlation between biochemical, physiological, and morphological parameters using Pearson's coefficient was demonstrated. A decline in lipid peroxidation was noticed in the FM-inoculated plants. In addition, we investigated the potential of $\mathrm{N}$ fertilizer application in combination with FM inoculation in maize plants. The FM-inoculated plants with organic O_LT, a chicken manure fertilizer, increased $\mathrm{N}$ content in the host shoots by $73 \%$ over the control, leading to improved $\mathrm{F}_{\mathrm{v}} / \mathrm{F}_{\mathrm{m}}$ as a physiological adaptation strategy. The FM and the O_LT on the regulation of the $\mathrm{N}$ enhancement and photosynthetic efficiency of the hybrid maize should further be validated in field trials in different environments for sustainability.
\end{abstract}

Keywords: arbuscular mycorrhizal fungi; nitrogen content; photosynthetic efficiency; organic fertilizer; maize

\section{Introduction}

Nitrogen, phosphorus, and potassium are major nutrients that regulate plant growth and development as well as plant phenology in crop species [1,2]. Nitrogen in different forms of fertilizer (i.e., ammonium $\left(\mathrm{NH}_{4}{ }^{+}\right)$and nitrate $\left(\mathrm{NO}_{3}{ }^{-}\right)$) has widely been applied in soil for plant cultivation and production $[3,4]$. In general, a $26 \%$ increase in production in major crops is linked to nitrogen fertilizer [5]. Excessive use of $\mathrm{N}$ fertilizer application and improper application methods result in reduced $\mathrm{N}$ use efficiency and increased $\mathrm{N}$ leaching, especially in maize cultivation [6]. It is thus imperative to optimize $\mathrm{N}$ implementation techniques that prevent $\mathrm{N}$ loss in the maize root zone [7]. The response of $\mathrm{N}$ fertilizer can regulate $\mathrm{N}$ status in plants and is associated with a prolonged green in maize leaves that serves the agricultural strategy of optimizing $\mathrm{N}$ use efficiency [8]. There are many low-input technologies for improving $\mathrm{N}$ availability in soil, such as $\mathrm{N}$-fixing legumes (green manure and legume crop rotation), AMF-root colonized plants, and soil microbe nitrogen transformation, leading to the retention of crop productivity [9].

As regards microbe symbionts, AMF have a role as a biofertilizer and serve to support a plant' quality advantage in agroecosystems [10]. At most, AMF symbiosis is able to improve a plant's physiological traits (i.e., photosynthetic efficiency, plant biomass, and 
yield [11-13]), and AMF also influence $\mathrm{N}$ uptake into the host plant [14,15]. Nonetheless, the $\mathrm{N}$ content in the host plant depends on the AMF taxa as observed with Acaulospora scrobiculata, Glomus etunicatum, G. mosseae, and G. versiforme symbiosis in walnut [16]. AMF taxa have specific functional regulation of $\mathrm{N}$ availability in soil, and plant performance varies with the type of AMF taxa used [17]. In addition, the $\mathrm{N}$ uptake facilitated by AMF mycelium, such as Rhizophagus irregularis, was not enough to maintain a sufficient $\mathrm{N}$ status in the host plants [18,19]. It is, thus, imperative to investigate various AMF taxa and N sources with the aim of maximizing the efficiency of an AMF-specific genus and $\mathrm{N}$ source.

Maize is one of the most important cereal crops, and it is widely cultivated in several regions of the world: USA (38.5\%), China (20.7\%), Brazil (9.1\%), European Union (5.8\%), and Argentina (4.0\%) [20]. It serves as raw materials of food, feed, and fuel (bioethanol) for the world's population, and its production is predicted to increase to 9735 million tons by the year 2050 [21]. Increased productivity of maize using hybrid genotypes (single cross- and double cross-breeding programs) is one of the most conventional strategies to fill the gap [22,23]. At present, hybrid $\mathrm{CP} 888^{\circledR}$ maize, a dominate genotype widely distributed at $>80 \%$ of the total area of maize cultivation in Thailand, Laos, Cambodia, and Vietnam [24,25], was selected as the candidate cultivar.

Recently, the reduced use of chemical-based agriculture cultivation techniques has become a trend in sustainable environmental crop production including maize. Divergent AMF that reflect an efficiency in $\mathrm{N}$ enhancement with photosynthetic regulation, pointing to a sufficient $\mathrm{N}$ status in the plant host for its development, together with alternative $\mathrm{N}$ sources was purposed. Therefore, this study investigated the potential of three AMF taxa-Funneliformis mossea, Claroideoglomus etunicatum, and Acaulospora foveata-and two organic $\mathrm{N}$ sources that matched in regard to $\mathrm{N}$ improvement and photosynthetic efficiency involving physiological fluctuations and growth characteristics in the hybrid $\mathrm{CP} 888^{\circledR}$ maize.

\section{Results}

\subsection{AMF Colonization, $N$ Content, and Plant Adaptation}

Root colonization by F. mosseae (FA), A. foveata (AF), and C. etunicatum (CE) was observed to be $67.5 \%, 57.5 \%$, and $65.0 \%$, respectively, compared to the control $(2.5 \%)$ (Figure 1). The hyphae and vesicle forms of FM, AF, and $\mathrm{CE}$ in the root tissues are given in Figure 1. The $\mathrm{N}$ content in the shoot and the root tissues of maize plants was regulated by all three types of AMF. In the shoots of plants inoculated with FM, AF, and CE, N content increased significantly by $21 \%, 21 \%$, and $14 \%$ over the control, respectively; whereas, in the root tissues, it was enhanced by $30 \%, 15 \%$, and $10 \%$, respectively (Figure 2). N regulation was thus observed to be AMF-specific, especially in the roots.

The leaf area and shoot and root weights of FM-inoculated maize were higher than the control by 1.5-, 1.6-, and 1.3-fold, respectively (Table 1). The shoot and root WC and TCh content were highest in the maize plants inoculated with FM (i.e., $14.27 \mathrm{mg} \mathrm{g}^{-1}, 62.42 \%$ and $52.74 \%$; Table 1 ). The $\mathrm{F}_{\mathrm{v}} / \mathrm{F}_{\mathrm{m}}$, maximum photosynthetic efficiency was regulated by AMF inoculation over the control (Table 1). Strong correlation coefficients were observed in FM-inoculated maize plants for shoot $\mathrm{N}$ and $\mathrm{F}_{\mathrm{v}} / \mathrm{F}_{\mathrm{m}}(r=0.92)$ and $\operatorname{root} \mathrm{N}$ and TCh $(r=1)$. Similarly, a strong correlation was observed in AF-inoculated maize plants between the shoot $\mathrm{N}$ and $\mathrm{F}_{\mathrm{v}} / \mathrm{F}_{\mathrm{m}}(r=1)$, but a negative correlation was found in root $\mathrm{N}$ content and TCh. In the case of CE-inoculated plants, a negative correlation was observed between $\mathrm{F}_{\mathrm{v}} / \mathrm{F}_{\mathrm{m}}$ and TCh and $\mathrm{N}$ content in both shoots and roots (Figure 3). After the period of AMF symbiosis, the malondialdehyde (MDA) content in the shoots of FM-, AF-, and CEinoculated plants was $17.97 \%, 15.59 \%$, and $3.26 \%$ lower than in the control, respectively, indicating the protective effects of AMF under the environmental conditions (Figure 4). FM inoculation was the most effective in reducing the MDA content in maize plants (Figure 4). 

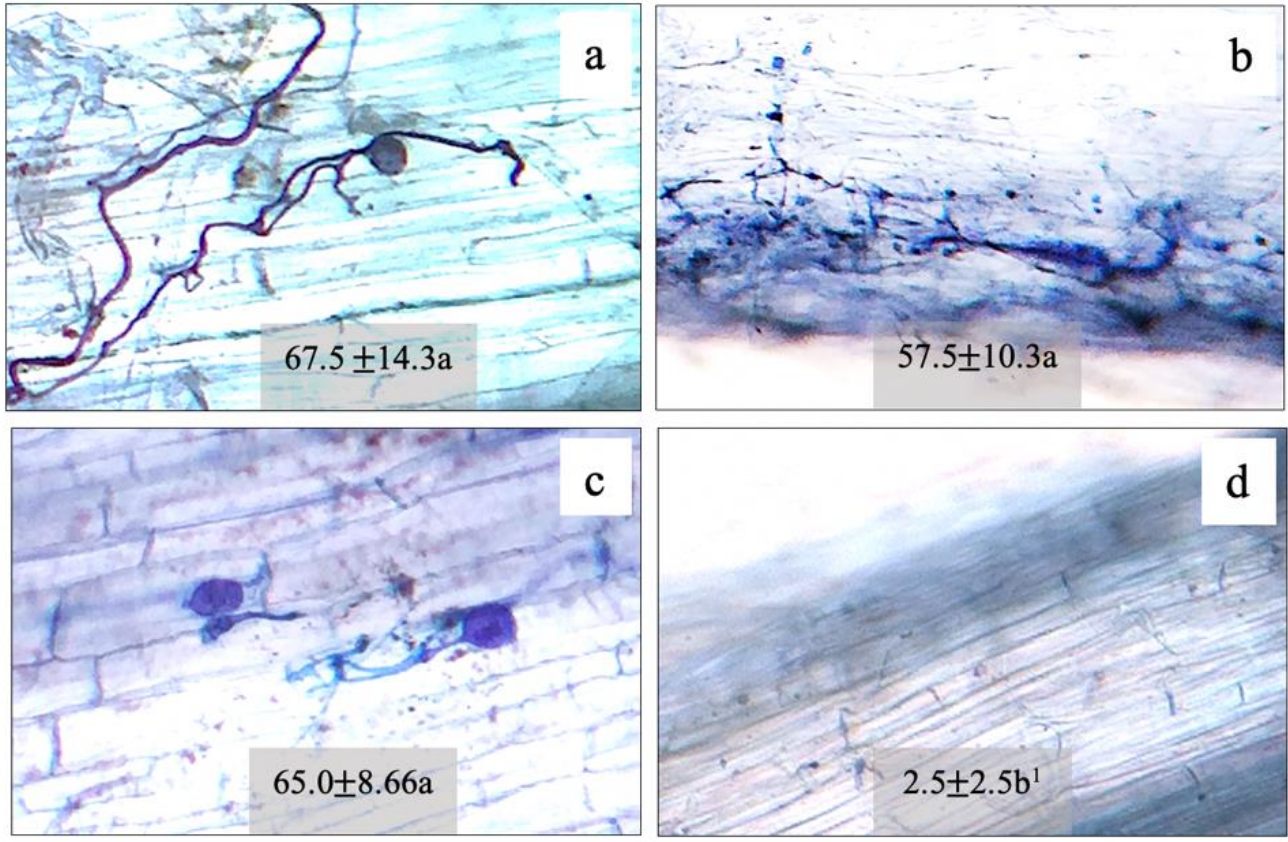

Figure 1. Morphological characters and root colonization of arbuscular mycorrhizal fungi: (a) Funneliformis mosseae (FM); (b) Acaulospora foveata (AF); (c) Claroideoglomus etunicatum (CE); (d) control (Con) in the hybrid maize host. ${ }^{1}$ Mean \pm SE. The different letters indicate significant data at $p \leq 0.01$ using Duncan's new multiple range test.
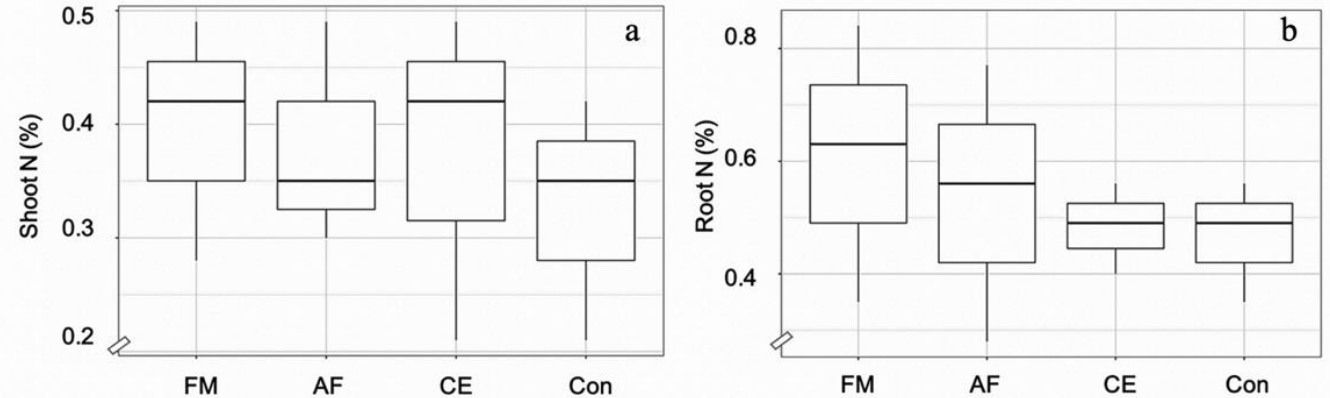

Figure 2. Box plots showing $N$ content in the shoots (a) and roots (b) of the hybrid maize inoculated with Funneliformis mosseae (FM), Acaulospora foveata (AF), and Claroideoglomus etunicatum (CE) and the uninoculated control (Con). Data sorted by means.

Table 1. Mean of total chlorophyll content (TCh), photosynthetic efficiency $\left(\mathrm{F}_{\mathrm{v}} / \mathrm{F}_{\mathrm{m}}\right)$, leaf area, shoot and root fresh weight (FW), and their water content (WC) in shoots and roots of the hybrid maize inoculated with Funneliformis mosseae (FM), Acaulospora foveata (AF), and Claroideoglomus etunicatum (CE) and the uninoculated control (Con).

\begin{tabular}{|c|c|c|c|c|c|c|c|}
\hline Treatment & $\begin{array}{c}\text { TCh } \\
\left(\mathrm{mg} \mathrm{g}^{-1} \mathrm{FW}\right)\end{array}$ & $F_{v} / F_{m}$ & $\begin{array}{l}\text { Leaf Area } \\
\left(\mathrm{cm}^{2}\right)\end{array}$ & $\begin{array}{l}\text { Shoot FW } \\
\left.\text { (g plant }^{-1}\right)\end{array}$ & $\begin{array}{c}\text { Root FW } \\
\left.\text { (g plant }^{-1}\right)\end{array}$ & Shoot WC (\%) & $\begin{array}{l}\text { Root WC } \\
(\%)\end{array}$ \\
\hline Con & $11.52 \pm 2.05$ & $0.61 \pm 0.05$ & $37.57 \pm 8.12 b$ & $1.30 \pm 0.39 b$ & $1.40 \pm 0.14 \mathrm{ab}$ & $43.73 \pm 3.24 b$ & $42.17 \pm 4.02 b$ \\
\hline FM & $14.27 \pm 2.25$ & $0.65 \pm 0.09$ & $55.62 \pm 18.18 a$ & $2.08 \pm 0.59 a$ & $1.76 \pm 0.30 \mathrm{a}$ & $62.42 \pm 4.24 \mathrm{a}$ & $52.74 \pm 11.31 \mathrm{a}$ \\
\hline $\mathrm{AF}$ & $10.01 \pm 0.82$ & $0.68 \pm 0.02$ & $49.19 \pm 11.71 \mathrm{ab}$ & $1.88 \pm 0.28 \mathrm{ab}$ & $0.87 \pm 0.09 \mathrm{~b}$ & $45.76 \pm 0.39 b$ & $48.30 \pm 12.22 \mathrm{ab}$ \\
\hline $\mathrm{CE}$ & $13.01 \pm 1.78$ & $0.64 \pm 0.09$ & $45.98 \pm 5.69 \mathrm{ab}$ & $1.59 \pm 0.24 \mathrm{ab}$ & $1.37 \pm 0.17 a b$ & $44.25 \pm 7.33 \mathrm{~b}$ & $47.95 \pm 3.36 \mathrm{ab}$ \\
\hline ANOVA & ns & ns & * & * & ** & ** & * \\
\hline
\end{tabular}

Different letters in a column represent significant differences among treatments at $p \leq 0.05$ applying Duncan's new multiple range test. $\mathrm{ns}, * *$, and ${ }^{* *}$ represent non-significant, significant at $p \leq 0.05$, and significant at $p \leq 0.01$, respectively. 


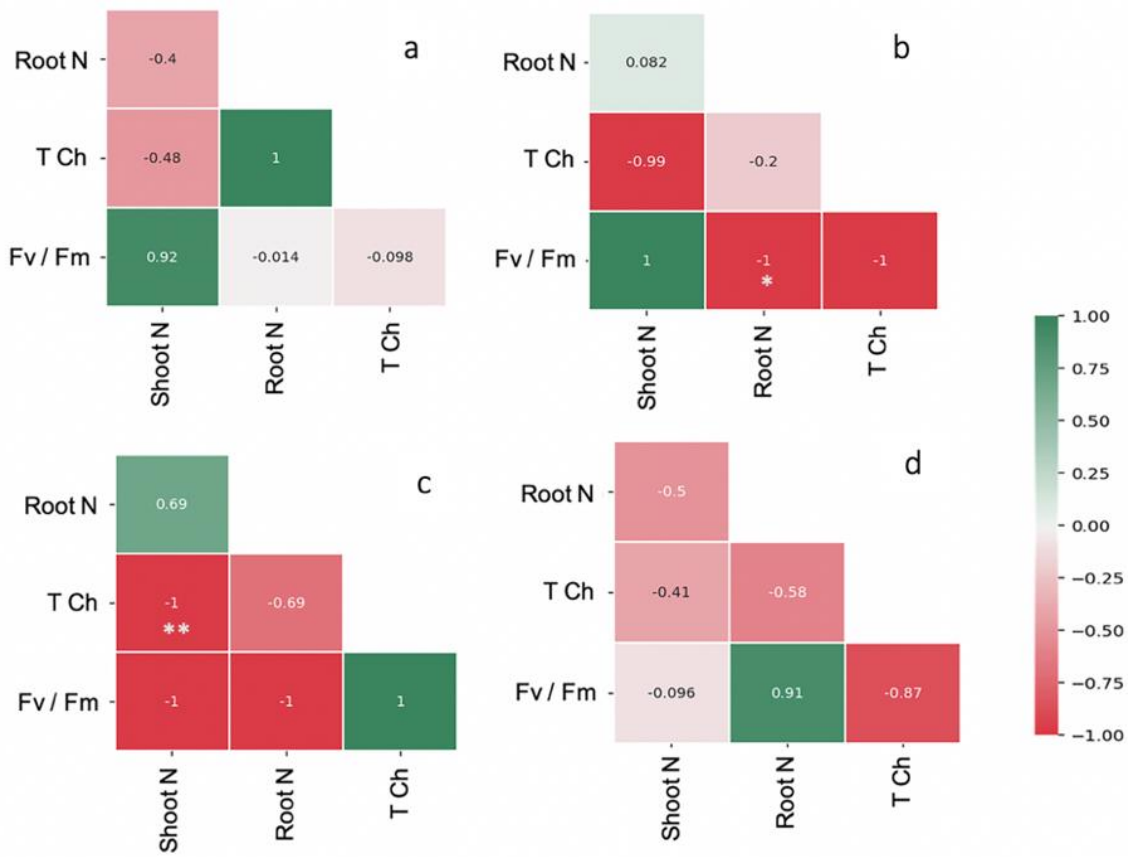

Figure 3. Pearson correlation coefficient matrices depicting relationship between $\mathrm{N}$ content and total chlorophyll content, photosynthetic efficiency $\left(\mathrm{F}_{\mathrm{v}} / \mathrm{F}_{\mathrm{m}}\right)$ of the hybrid inoculated with (a) Funneliformis mosseae (FM), (b) Acaulospora foveata (AF), and (c) Claroideoglomus etunicatum (CE) and the (d) uninoculated control (Con). Scale from a -1 to 1 coefficient. Data were significant at ${ }^{* *} p \leq 0.01$ and ${ }^{*} p \leq 0.05$ using Duncan's new multiple range test.

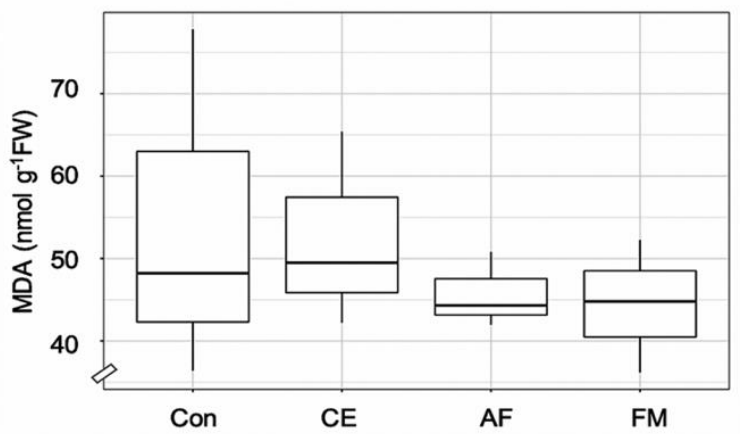

Figure 4. Box plot showing malondialdehyde (MDA) content in the shoots of the hybrid maize inoculated with Claroideoglomus etunicatum (CE), Acaulospora foveata (AF), and Funneliformis mosseae (FM) and the uninoculated control (Con). Data sorted by means.

The clustering of an integration of the studied parameters was mapped to confirm the AMF-plant characteristics. Hierarchical clustering separated the plants' physiological, biochemical, and growth parameters into three groups: (1) control (uninoculated) and CE-inoculated plants, (2) AF-inoculated plants, and (3) FM-inoculated plants. The greatest upregulation of growth characteristics was observed in the CP888 ${ }^{\circledR}$ maize inoculated with the FM-type AMF (Figure 5). In contrast, the characteristics of the CE-inoculated plants closely resembled those of the uninoculated control plants.

\subsection{AMF Modulated N Improvement in Maize Plants}

Based on the results of Experiment-I, FM was selected for Experiment-II. The relative N content in the shoots of the FM-inoculated plants with supplementation of the two organic fertilizers, O_LT and O_UMJ, increased by $73.57 \%$ and $58.57 \%$ and decreased slightly $(1.42 \%)$ with supplementation of the chemical fertilizer (i.e., C_UR) compared to the control. 
However, the relative photosynthetic efficiency was remarkable in the FM-inoculated plants supplemented with organic fertilizer (O_LT) (Figure 6).

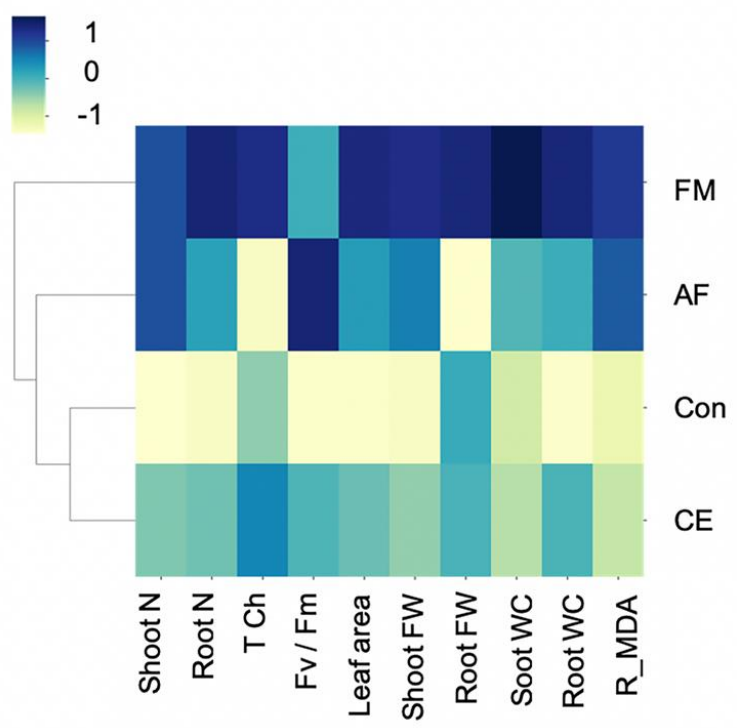

Figure 5. Heat map clustering (as Z-score values) of shoot and root $\mathrm{N}$ content, fresh weight, water content, total chlorophyll content, photosynthetic efficiency, and reversed MDA content of the hybrid maize inoculated with Funneliformis mosseae (FM), Claroideoglomus etunicatum (CE), and Acaulospora foveata (AF) and the uninoculated control (Con).

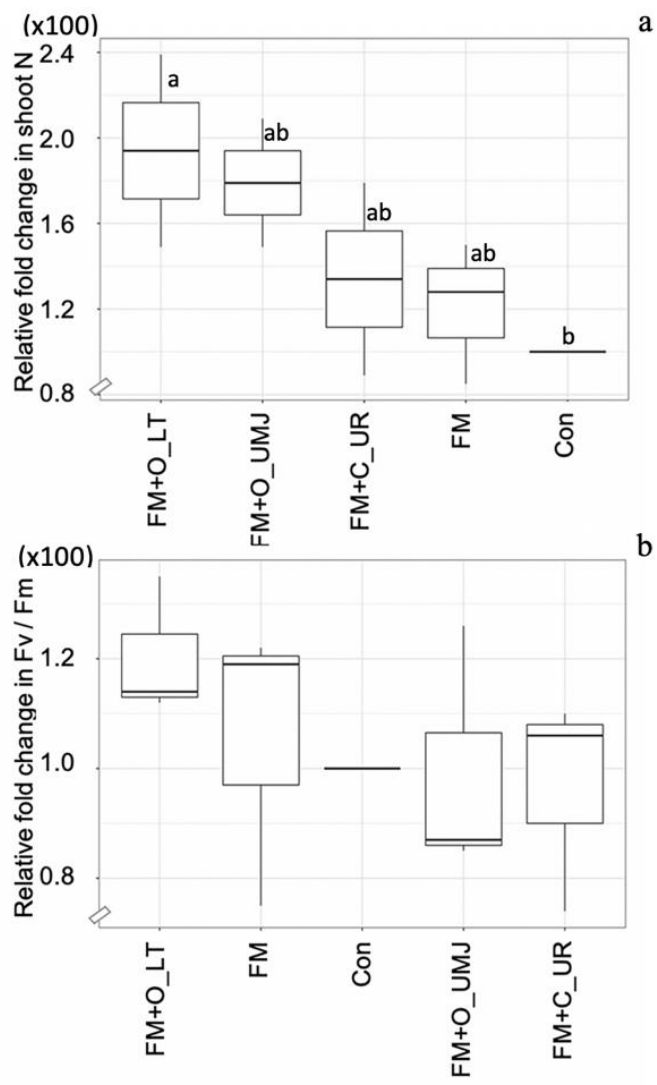

Figure 6. Box plots representing relative changes in $\mathrm{N}$ content (a) and photosynthetic efficiency $\left(\mathrm{F}_{\mathrm{v}} / \mathrm{F}_{\mathrm{m}}\right)(\mathrm{b})$ in the shoots of the hybrid maize plant inoculated with Funneliformis mosseae (FM) with/without organic fertilizers (i.e., O_LT and O_UMJ), chemical fertilizer (i.e., C_UR), and the uninoculated control (Con). Data sorting by means. Different letters indicate significant differences at $p \leq 0.05$ applying Duncan's new multiple range test. 


\section{Discussion}

Changes in the maize $\mathrm{N}$ response were assessed using different $\mathrm{AMF}$ (i.e., $\mathrm{FM}, \mathrm{AF}$, and CE) inoculation and two types of organic fertilizers (i.e., O_LT and O_UMJ) fertilizers. The $\mathrm{N}$ content in maize plants with/upon AMF inoculation might be related to the ability of AMF extraradical mycelium to modulate $\mathrm{N}_{2}$ uptake into intra-mycelium and, ultimately, to the host plant [14]. Variations in N uptake by different AMF species have also been observed in the roots of walnut, where the highest nitrogen uptake was mediated by inoculation of Glomus etunicatum, or CE, (15.86 $\left.\mathrm{g} \mathrm{kg}^{-1} \mathrm{DW}\right)$, followed by G. mosseae, or FM, $\left(9.78 \mathrm{~g} \mathrm{~kg}^{-1}\right.$ $\mathrm{DW}$ ) and Acaulospora scrobiculata (8.27 $\mathrm{g} \mathrm{kg}^{-1} \mathrm{DW}$ ) [16]. Likewise, AMF-specific variations in $\mathrm{N}$ uptake were reported in mulberry by Shi et al. [26]. These variations might be due to the intraspecific diversity in the fungal $\mathrm{N}$ transporters and the plant host [27] as observed with AMF-maize symbiosis in the present study.

The grouping of the maize performance based on the intergraded framework of the plant characteristics revealed the differences in three AMF-inoculated maize. The greater performance of $\mathrm{FM}$ and $\mathrm{AF}$ with the host plant was corroborated by the investigation of Shi et al. [26]. In mulberry, F. mosseae and A. scrobiculata also depicted a positive response on growth improvement and development quality in total leaf $\mathrm{N}$, photosynthetic pigment, and transpiration. On the other hand, shoot $\mathrm{N}$ and photosynthetic efficiency displayed strong positive correlations in both FM- and AF-inoculated plants. However, the strong positive correlation of root $\mathrm{N}$ with chlorophyll content was found only in the FM-inoculated plants. Wang et al. [28] suggested that FM inoculation was effective for improving $\mathrm{N}$ content in plants, including their roots, and chlorophyll content in Gleditsia triacanthos tree. As regards nitrogen improvement, the large amount of $\mathrm{N}$ flux in the AMF-host plants was reflected in the high carbon turnover to AMF intra-mycelium in the symbiosis [29]. In potato, with an increase in the $\mathrm{N}$ dose, a positive correlation between chlorophyll content and plant/tuber yield was observed, but the chlorophyll content and $\mathrm{F}_{\mathrm{v}} / \mathrm{F}_{\mathrm{m}}$ were negatively correlated [30]. Based on the obtained results, it is assumed that $\mathrm{N}$ regulation in the FM symbiosis takes precedence with high efficiency into root tissue compartments and a positive correlation in chlorophyll development compared to the AF and CE types.

MDA is a known indicator of cellular damage and is dependent on its cellular accumulation and dynamic regulation [31]. Reduction in MDA levels after AMF inoculation indicated involvement in the mitigation of plant membrane damage [32] through proteins and nucleic acids modification and interference with the photosystem and membrane fluidity, therefore leading to increased host plant development [31].

The increased $\mathrm{N}$ content of the plants supplemented with FM and two organic fertilizers plus the FM inoculation (Figure 6) was supported by a previous study reporting that the substantial ${ }^{15} \mathrm{~N}$ uptake was up to $31 \%$ into extraradical Glomus hyphae from a decomposed organic patch, implying and recognizing that AMF and organic material perform a role in the global $\mathrm{N}$ pool and are involved in $\mathrm{N}$ cycling [33]. It is possible that the increased $\mathrm{N}$ uptake in the FM-treated maize with the two organic fertilizers was more effective than the chemical fertilizer. However, the relative $\mathrm{F}_{\mathrm{v}} / \mathrm{F}_{\mathrm{m}}$ in the maize plants only showed the capability of the O_LT organic fertilizer, a chicken manure type. The reason for such an observation is not known; however, it is related to rich amino acid content in the chicken manure type (10.16-17.31\% per dry weight), while cattle manure contained $7.61-10.89 \%$ amino acid content [34]. AMF (Glomus hoi and G. intraradices) degrade various types of organic $\mathrm{N}$ residues, proteins, and peptides into amino acid and translocate them from the extraradical mycelium to host plant [35]. In addition, an increase in soil enzyme activity highlight the influence of bio-organic fertilizer [36] related to AMF [37]. Moreover, organic plant manure was indicated to have higher induced soil enzyme activity rather than animal manure [38], while the enzyme activity in the organic chicken manure (i.e., O_LT) may be higher than in the plant plus cattle compost (i.e., O_UMJ), resulting in released $\mathrm{N}$ in plant-AMF symbiosis, (Figure 6). It was assumed that the supply of several mineralized $\mathrm{N}$ forms by O_LT organic sources was through the regulation of FM hyphae, leading to the 
efficiency of the soil enzyme activity, which was due both to improved $\mathrm{N}$ content and the photosynthetic efficiency in the FM plus O_LT plant.

Indeed, the altered $\mathrm{N}$ content and photosynthetic regulation were most distinguished in the results of the FM and the O_LT influences on the maize compared with previous reports as shown in Table 2. In this study, the FM may provide the utmost relevance to the O_LT fertilizer in terms of the plant-soil-microbe system, reflecting maize development over the long term, at least in Thailand's climate. This may be supported by the balanced management of organic $\mathrm{N}$ fertilizer, which is positively correlated with the microorganism population and soil enzyme activity, resulting in improved plant yield, including soilbio/physical properties over the long-term for sustainability [36,39].

Table 2. Study approaches with/without plant nitrogen (N) and photosynthetic regulation (PR), displaying AMF's and/or fertilizer's different influences compared to the current study.

\begin{tabular}{|c|c|c|c|c|}
\hline $\begin{array}{c}\text { Study Approach } \\
\text { with/without, } \\
\text { Involving } \mathrm{N} \text { and } \mathrm{PR}\end{array}$ & Priority Effective AMF & Fertilizer Consideration & Plant Host & Reference \\
\hline $\mathrm{N}$ and $\mathrm{PR}$ & Funneliformis mosseae & $\begin{array}{c}\text { Type comparing } \\
\text { (Plant/animal manure organic } \\
\text { and chemical fertilizer) }\end{array}$ & $\begin{array}{c}\text { Maize } \\
\text { (Zea mays L.) }\end{array}$ & This study \\
\hline $\mathrm{N}$ and $\mathrm{PR}$ & $\begin{array}{l}\text { Glomus etunicatum, } \\
\text { Diversispora spurca }\end{array}$ & $\mathrm{ns}^{1}$ & $\begin{array}{c}\text { Walnuts } \\
\text { (Juglans regia L.) }\end{array}$ & [16] \\
\hline $\begin{array}{c}\mathrm{N} \text { and } \mathrm{PR} \\
\text { (Under drought) }\end{array}$ & Rhizophagus irregularis & $\begin{array}{c}\text { ns } \\
\text { (Chemical dose) }\end{array}$ & $\begin{array}{c}\text { Maize } \\
\text { (Zea mays L.) }\end{array}$ & [19] \\
\hline $\mathrm{N}$ and $\mathrm{PR}$ & $\begin{array}{l}\text { Funneliformis mosseae, } \\
\text { Acaulospora scrobiculata }\end{array}$ & ns & $\begin{array}{c}\text { Mulberry } \\
\text { (Morus alba L.) }\end{array}$ & [26] \\
\hline $\mathrm{N}$ without $\mathrm{PR}$ & $\begin{array}{c}\text { Mix of Rhizophagus } \\
\text { irregularis and } \\
\text { Funneliformis mosseae }\end{array}$ & $\begin{array}{l}\text { Type comparing } \\
\text { (Plant residue and } \\
\text { mineral fertilizer) }\end{array}$ & $\begin{array}{l}\text { Durum wheat } \\
\text { (Triticum durum Desf.) }\end{array}$ & [15] \\
\hline $\mathrm{N}$ without $\mathrm{PR}$ & Rhizophagus irregularis & $\begin{array}{c}\text { ns } \\
\text { (Chemical dose) }\end{array}$ & $\begin{array}{c}\text { Poplar } \\
\text { Populus } \times \text { canadensis) }\end{array}$ & [40] \\
\hline $\mathrm{N}$ without $\mathrm{PR}$ & Rhizophagus irregularis & $\mathrm{ns}$ & $\begin{array}{c}\text { Poplar } \\
\text { (Populus } \times \text { canadensis })\end{array}$ & [41] \\
\hline $\mathrm{N}$ without $\mathrm{PR}$ & $\begin{array}{l}\text { Rhizophagus aggregatum } \\
\text { (plus Rhizobium) }\end{array}$ & $\begin{array}{c}\mathrm{ns} \\
\text { (Plant organic fertilizer test) }\end{array}$ & $\begin{array}{c}\text { Maize } \\
\text { (Zea mays L.) }\end{array}$ & [42] \\
\hline $\mathrm{N}$ without $\mathrm{PR}$ & Rhizophagus irregularis & ns & $\begin{array}{c}\text { Legumes } \\
\text { (Medicago spp.) }\end{array}$ & [43] \\
\hline $\begin{array}{c}\text { Without N, PR } \\
\text { (Dry matter, yield) }\end{array}$ & Glomus aggregatum & $\begin{array}{c}\text { ns } \\
\text { (Chemical dose) }\end{array}$ & $\begin{array}{c}\text { Maize } \\
\text { (Zea mays L.) }\end{array}$ & [44] \\
\hline $\begin{array}{l}\text { Without N, PR } \\
\text { (Growth parameters, } \\
\text { phosphorus uptake) }\end{array}$ & Glomus spp. & ns & $\begin{array}{c}\text { Maize } \\
\text { (Zea mays L.) }\end{array}$ & [45] \\
\hline
\end{tabular}

${ }^{1}$ ns-Fertilizer types were not considered in study.

\section{Materials and Methods}

\subsection{Plant Material and Treatments}

Seeds of maize (Zea mays L.; hybrid genotype CP888 ${ }^{\circledR}$, Charoen Pokphand Produce, Bangkok, Thailand) are commonly cultivated on sloping land in the north of Thailand [46]. Three seeds per pot were geminated and grown in sterilized soil. The soil $(0.18 \% \mathrm{~N}$, $0.12 \% \mathrm{P}, 0.13 \% \mathrm{~K}$, and $11.19 \%$ organic matter with $\mathrm{pH} 5.58$ and an electro conductivity of $1.08 \mathrm{dS} \mathrm{m}^{-1}$ ) was sterilized using an autoclave at $121^{\circ} \mathrm{C}$ for $15 \mathrm{~min}$. For sterilization, it was mixed together with sand $(1: 2, w / w)$ poured into 12 inch plastic pots $(2 \mathrm{~kg}$ substrate in each pot) with arbuscular mycorrhizal fungi inoculation. Two-hundred and fifty spores of mycorrhizal fungi, namely, (1) Funneliformis mosseae (T.H. Nicolson \& Gerd.) C. Walker \& A. Schüßler, formerly known as Glomus mosseae, hereafter FM; (2) Claroideoglomus etunicatum (W.N. Becker \& Gerd.) C. Walker \& A. Schüßler, formerly known as G. etunicatum, hereafter 
CE; (3) Acaulospora foveata (Trappe \& Janos), hereafter AF, were inoculated before planting as Experiment I. After two months (V4 stage of corn vegetative growth), the root samples were collected for $\mathrm{AMF}$ colonization, and leaf $\mathrm{N}$ content, lipid peroxidation, photosynthetic abilities, and growth measurements were determined.

In Experiment II, a high potential AMF taxon from Experiment I was selected to evaluate symbiosis in combination with fertilizer utilization in terms of $\mathrm{N}$ content. Maize seedlings were germinated and grown in similar way as in Experiment I and inoculated with the best AMF type in combination with three $\mathrm{N}$ enriched fertilizers. The 1st treatment was organic fertilizer based on a chicken manure $(4.30 \% \mathrm{~N})\left(\mathrm{O} \_\right.$LT; Donk Bua $\left.{ }^{\circledR}\right)$, and the 2nd treatment was organic fertilizer based on a plant plus cattle compost $(5.08 \% \mathrm{~N})\left(\mathrm{O} \_\mathrm{UMJ}\right)$. The major nutrients and both the manures are given in Table S1. A positive check control treatment was included and indicated as chemical fertilizer (C_UR) composed of $2.43 \mathrm{~g}$ urea (46-0-0). Alternatively, the organic fertilizers, O_LT and O_UMJ, were autoclaved before the application. These organic fertilizers were applied at 26.06 and $22.06 \mathrm{~g} \mathrm{pot}^{-1}$, according to recommendation by the Department of Agriculture, Thailand (218.75-kg N per hectare). The $\mathrm{N}$ content and photosynthetic efficiency in their leaves were evaluated and calculated relative to the change in control after two months (i.e., V4 stage).

\subsection{AMF Colonization Analysis}

AMF colonization was detected by mycorrhizal symbiosis in the roots of the hosted maize plants as per Yooyongwech et al. [13]. In brief, one centimeter of maize roots was collected and kept in $60 \%$ ethanol. Added to the root samples was $10 \% \mathrm{KOH}$ (Sigma, Marlborough, MA, USA) and then boiled at $95^{\circ} \mathrm{C}$ for $30 \mathrm{~min}$. Next, root pieces were then cleaned and strained with $0.05 \%$ trypan blue (Sigma, Marlborough, MA, USA) for $15 \mathrm{~min}$. The number of arbuscules, vesicles, and hyphae of the mycorrhizal fungi were practically processed and observed under a light microscope, and the percentage of the colonization was calculated.

\subsection{Total N Determination}

The $\mathrm{N}$ content in the leaf tissues was analyzed by the Kjeldahl method [47]. Fivehundred milligrams of shoot and root tissues were weighed and transferred into digestion tubes. Then, $20 \mathrm{~mL}$ of $36 \%$ sulfuric acid (Merck, NJ, USA) and 2 tablets of Kjeltab (Buchi, UK) were added to the tubes. The digestion was subsequently performed by heating at $420{ }^{\circ} \mathrm{C}$ for $50 \mathrm{~min}$. After cooling the sample, $90 \mathrm{~mL}$ of deionized water and $80 \mathrm{~mL}$ of $32 \%$ $\mathrm{NaOH}$ (Sigma, Marlborough, MA, USA) were added. The distillation was then processed for $4 \mathrm{~min}$. The ammonia released by water stream distillation was trapped in $80 \mathrm{~mL}$ of $2 \%$ $\mathrm{H}_{3} \mathrm{BO}_{3}$ (Sigma, Marlborough, MA, USA). It was then titrated against $0.05 \mathrm{~mol} \mathrm{~L}^{-1} \mathrm{H}_{2} \mathrm{SO}_{4}$ until the color changed from green to violet. The $\% \mathrm{~N}$ was calculated using the equation:

$$
\mathrm{N}(\%)=1.4007 \times \mathrm{C} \times\left(\mathrm{V}-\mathrm{V}_{\mathrm{B}}\right) / \mathrm{W},
$$

where 1.4007-conversion factor, milliequivalent weight of $\mathrm{N}$;

C-concentration of standard $\mathrm{H}_{2} \mathrm{SO}_{4}$ solution $\left(\mathrm{mol} \mathrm{L}^{-1}\right)$;

$\mathrm{V}$-consumption of standard $\mathrm{H}_{2} \mathrm{SO}_{4}$ for sample $(\mathrm{mL})$;

$\mathrm{V}_{\mathrm{B}}$ - consumption of standard;

$\mathrm{H}_{2} \mathrm{SO}_{4}$ for blank sample (mL);

$\mathrm{W}$-initial sample weight $(\mathrm{g})$.

\subsection{Determination of Chlorophyll Content, Photosynthetic Efficiency, and Growth Character}

Total chlorophyll content (TCh) in the second fully expanded leaf was analyzed as photosynthetic pigments. In brief, a hundred milligrams of leaf samples were weighed and transferred to test tubes. Then, $5 \mathrm{~mL}$ of $95 \%$ acetone was added (Sigma, Marlborough, MA, USA), homogenized, and kept in darkness at $4{ }^{\circ} \mathrm{C}$ for $48 \mathrm{~h}$. The supernatant was collected, and the absorbance was recorded at 645,662 , and $470 \mathrm{~nm}$, and the pigment content was calculated using the method of Shabala et al. [48]. 
A sensitive indicator of the photosynthetic performance in plants, a maximum photosynthetic efficiency $\left(\mathrm{F}_{\mathrm{v}} / \mathrm{F}_{\mathrm{m}}\right)$, [49] were measured according to Maxwell and Johnson [50]. In brief, leaf clips were practically conducted, and dark adapted for $30 \mathrm{~min}$ on the leaf surface of the fully expand leaves (2-3rd upper leaf from shoot tip), and then the $F_{V} / F_{m}$ were recorded.

Shoot and root weights were measured, and the percentage of water content (WC) was calculated in shoot and root tissues according to the formula: \% water content $=(\mathrm{FW}-\mathrm{DW}) / \mathrm{FW} \times 100$, where FW-fresh weight, and DW-dry weight [13]. In addition, the second to third leaves were selected to estimate the leaf area.

\subsection{Malondialdehyde Analysis}

A lipid peroxidation assay was determined by measuring the MDA content in the leaf tissues following the method given by Zhou et al. [51]. In brief, $0.5 \mathrm{~g}$ of shoot powder mixed with $3 \mathrm{~mL}$ of $50 \mathrm{mM}$ potassium phosphate buffer $(\mathrm{pH} 7.8)$ were centrifuged at $12,000 \times g$ for $20 \mathrm{~min}$. One milliliter of supernatant was collected and then added with $3 \mathrm{~mL}$ of $0.5 \%$ thiobarbituric acid (Sigma, Marlborough, MA, USA) and incubated at $95{ }^{\circ} \mathrm{C}$ in water bath for $60 \mathrm{~min}$. After cooling, the absorbance was determined at 532 and $600 \mathrm{~nm}$, and the MDA content was calculated using an extinction value of $155 \mathrm{mM}^{-1} \mathrm{~cm}^{-1}$ and adapted to per gram fresh weight.

\subsection{Experimental Layout and Statistical Analysis}

In the experiment, the box plots were median, interquartile range at $25-75 \%$ with standard deviation, and the data values were sequenced by mean. One-way analysis of variance (ANOVA) was applied to test significant differences in different treatments using $n=3$, except colonization $(n=6)$. Data were analyzed by post hoc Duncan's new multiple range test. The Pearson correlation coefficient matrix was determined as a linear correlation between chlorophyll content and the photosynthetic efficiency related to the response of the $\mathrm{N}$ content. In addition, the linkages in $\mathrm{N}$ content, physiology, growth, and a reversed MDA were analyzed by hierarchical clustering. The statistical analyses were performed in Jamovi ver.1.6.18.0, an open-source software based on R (https:/ / www.jamovi.org, accessed on 17 October 2021).

\section{Conclusions}

In this study, inoculation of maize plants with the AMF F. mosseae and A. foveata improved the maize's characteristics. The F. mosseae-treated maize plants showed a positive correlation of root $\mathrm{N}$ content with chlorophyll content and shoot $\mathrm{N}$ with $\mathrm{F}_{\mathrm{v}} / \mathrm{F}_{\mathrm{m}}$. In addition, the F. mosseae-treated plants exhibited the lowest lipid peroxidation and played a vital role in $\mathrm{N}$ assimilation upon application with the organic fertilizers (i.e., O_UMJ and O_LT). However, the photosynthetic efficiency in the maize plants was sharply affected by F. mosseae plus the O_LT (chicken manure type). Moreover, the maize treated with C. etunicatum had a weaker development response and clustered closely with the untreated maize. Nevertheless, the ability of the AMF taxon F. mosseae in boosting plant $\mathrm{N}$ content and that of the organic fertilizer O_LT to regulate $\mathrm{N}$ implies an important role for the maize photosynthetic regulation for long-term sustainability.

Supplementary Materials: The following are available online at https:/ /www.mdpi.com/article/10 .3390 / plants11030369/s1, Table S1: Major nutrients in the organic fertilizers.

Author Contributions: Conceptualization, S.Y. and S.C.; methodology, S.Y.; software, S.Y.; investigation, S.Y., W.T., R.T., D.C., and T.S.; data curation, S.Y., W.T., D.C., and S.C.; writing-original draft preparation, S.Y. and W.T.; writing-review and editing, S.Y. and W.T.; supervision, S.C. All authors have read and agreed to the published version of the manuscript.

Funding: This work was funded in part by a Thailand Research Fund (grant no. SRI5920201). The APC was supported by Central Mahidol University and the School of Interdisciplinary Studies, Kanchanaburi campus. 


\section{Institutional Review Board Statement: Not applicable.}

Informed Consent Statement: Not applicable.

Data Availability Statement: Not applicable.

Acknowledgments: We would like to thank Supatida Aumtong, Maejo University, for the production and provision of the AMF and the O_UMJ fertilizer; Papassara Bumroongsak for technical support; Siripong Thitamadee, Mahidol University, for manuscript guidance.

Conflicts of Interest: The authors declare no conflict of interest.

\section{References}

1. Mudau, N.F.; Soundy, P.; Du Toit, E.S. Plant growth and development of bush tea as affected by nitrogen, phosphorus, and potassium nutrition. HortScience 2005, 40, 1898-1901. [CrossRef]

2. Ye, T.; Li, Y.; Zhang, J.; Hou, W.; Zhou, W.; Lu, J.; Xing, Y.; Li, X. Nitrogen, phosphorus, and potassium fertilization affects the flowering time of rice (Oryza sativa L.). Glob. Ecol. Conserv. 2019, 20, e00753. [CrossRef]

3. Cao, P.; Lu, C.; Yu, Z. Historical nitrogen fertilizer use in agricultural ecosystems of the contiguous United States during 1850-2015: Application rate, timing, and fertilizer types. Earth Syst. Sci. Data 2018, 10, 969-984. [CrossRef]

4. Mueller, S.M.; Messina, C.D.; Vyn, T.J. Simultaneous gains in grain yield and nitrogen efficiency over 70 years of maize genetic improvement. Sci. Rep. 2019, 9, 9095. [CrossRef] [PubMed]

5. Stewart, W.M.; Dibb, D.W.; Johnston, A.E.; Smyth, T.J. The contribution of commercial fertilizer nutrients to food production. Agron. J. 2005, 97, 1-6. [CrossRef]

6. Jiang, C.; Lu, D.; Zu, C.; Shen, J.; Wang, S.; Guo, Z.; Zhou, J.; Wang, H. One-time root-zone N fertilization increases maize yield, NUE and reduces soil N losses in lime concretion black soil. Sci. Rep. 2018, 8, 10258. [CrossRef]

7. Jiang, C.; Lu, D.; Zu, C.; Zhou, J.; Wang, H. Root-zone fertilization improves crop yields and minimizes nitrogen loss in summer maize in China. Sci. Rep. 2018, 8, 15139. [CrossRef]

8. Fu, W.; Wang, Y.; Ye, Y.; Zhen, S.; Zhou, B.; Wang, Y.; Hu, Y.; Zhao, Y.; Huang, Y. Grain yields and nitrogen use efficiencies in different types of stay-green maize in response to nitrogen fertilizer. Plants 2020, 9, 474. [CrossRef]

9. Wang, X.X.; Wang, X.; Sun, Y.; Cheng, Y.; Liu, S.; Chen, X.; Feng, G.; Kuyper, T.W. Arbuscular mycorrhizal fungi negatively affect nitrogen acquisition and grain yield of maize in a $\mathrm{N}$ deficient soil. Front. Microbiol. 2018, 9, 418. [CrossRef]

10. Berruti, A.; Lumini, E.; Balestrini, R.; Bianciotto, V. Arbuscular mycorrhizal fungi as natural biofertilizers: Let's benefit from past successes. Front. Microbiol. 2016, 6, 1559. [CrossRef]

11. Gupta, S.; Thokchom, S.D.; Kapoor, R. Arbuscular mycorrhiza improves photosynthesis and restores alteration in sugar metabolism in Triticum aestivum L. grown in arsenic contaminated soil. Front. Plant Sci. 2021, 12, 640379. [CrossRef] [PubMed]

12. Wang, X.J.; Wang, X.X.; Feng, G. Optimised nitrogen fertiliser management achieved higher diversity of arbuscular mycorrhiza fungi and high-yielding maize (Zea mays L.). Crop Pasture Sci. 2015, 66, 706-714. [CrossRef]

13. Yooyongwech, S.; Phaukinsang, N.; Cha-um, S.; Supaibulwatana, K. Arbuscular mycorrhiza improved growth performance in Macadamia tetraphylla L. grown under water deficit stress involves soluble sugar and proline accumulation. Plant Growth Regul. 2013, 69, 285-293. [CrossRef]

14. Govindarajulu, M.; Pfeffer, P.E.; Jin, H.; Abubaker, J.; Douds, D.D.; Allen, J.W.; Büking, H.; Lammers, P.J.; Shachar-Hill, Y. Nitrogen transfer in the arbuscular mycorrhizal symbiosis. Nature 2005, 435, 819-823. [CrossRef]

15. Ingraffia, R.; Amato, G.; Sosa-Hernández, M.A.; Frenda, A.S.; Rillig, M.C.; Giambalvo, D. Nitrogen type and availability drive mycorrhizal effects on wheat performance, nitrogen uptake and recovery, and production sustainability. Front. Plant Sci. 2020, 11, 760. [CrossRef]

16. Huang, G.M.; Zou, Y.N.; Wu, Q.S.; Xu, Y.J.; Kuča, K. Mycorrhizal roles in plant growth, gas exchange, root morphology, and nutrient uptake of walnuts. Plant Soil Environ. 2020, 66, 295-302. [CrossRef]

17. Treseder, K.K.; Allen, E.B.; Egerton-Warburton, L.M.; Hart, M.M.; Klironomos, J.N.; Maherali, H.; Tedersoo, L. Arbuscular mycorrhizal fungi as mediators of ecosystem responses to nitrogen deposition: A trait-based predictive framework. J. Ecol. 2018, 106, 480-489. [CrossRef]

18. Hawkins, H.J.; George, E. Effect of plant nitrogen status on the contribution of arbuscular mycorrhizal hyphae to plant nitrogen uptake. Physiol. Plant 1999, 105, 694-700. [CrossRef]

19. Polcyn, W.; Paluch-Lubawa, E.; Lehmann, T.; Mikuła, R. Arbuscular mycorrhiza in highly fertilized maize cultures alleviates short-term drought effects but does not improve fodder yield and quality. Front. Plant Sci. 2019, 10, 496. [CrossRef]

20. Arumugam, A.; Malolan, V.V.; Ponnusami, V. Contemporary pretreatment strategies for bioethanol production from corncobs: A comprehensive review. Waste Biomass Valori. 2021, 12, 577-612. [CrossRef]

21. Ray, D.K.; Mueller, N.D.; West, P.C.; Foley, J.A. Yield trends are insufficient to double global crop production by 2050. PLoS ONE 2013, 8, e66428. [CrossRef] [PubMed]

22. Meng, Q.; Hou, P.; Wu, L.; Chen, X.; Cui, Z.; Zhang, F. Understanding production potentials and yield gaps in intensive maize production in China. Field Crops Res. 2013, 143, 91-97. [CrossRef] 
23. Schulthess, U.; Timsina, J.; Herrera, J.M.; McDonald, A. Mapping field-scale yield gaps for maize: An example from Bangladesh. Field Crops Res. 2013, 143, 151-156. [CrossRef]

24. Blake, D.J.; Thiengburanathum, P.; Thiengburanathum, P.; Friend, R.M.; Doherty, B.; Thankappan, S. Looking at complex agri-food systems from an actor perspective: The case of Northern Thailand. Adv. Food Secur. Sustain. 2019, 4, 33-65. [CrossRef]

25. Yap, V.Y.; Xaphokhame, P.; de Neergaard, A.; Bech Bruun, T. Barriers to agro-ecological intensification of smallholder upland farming systems in Lao PDR. Agronomy 2019, 9, 375. [CrossRef]

26. Shi, S.M.; Chen, K.; Gao, Y.; Liu, B.; Yang, X.H.; Huang, X.Z.; Liu, G.X.; Zhu, L.Q.; He, X.H. Arbuscular mycorrhizal fungus species dependency governs better plant physiological characteristics and leaf quality of mulberry (Morus alba L.) seedlings. Front. Microbiol. 2016, 7, 1030. [CrossRef] [PubMed]

27. Bücking, H.; Kafle, A. Role of arbuscular mycorrhizal fungi in the nitrogen uptake of plants: Current knowledge and research gaps. Agronomy 2015, 4, 587-612. [CrossRef]

28. Wang, J.; Zhong, H.; Zhu, L.; Yuan, Y.; Xu, L.; Wang, G.G.; Zhai, L.; Yang, L.; Zhang, J. Arbuscular mycorrhizal fungi effectively enhance the growth of Gleditsia sinensis Lam. seedlings under greenhouse conditions. Forests 2019, 10, 567. [CrossRef]

29. Fellbaum, C.R.; Gachomo, E.W.; Beesetty, Y.; Choudhari, S.; Strahan, G.D.; Pfeffer, P.E.; Kiersd, E.T.; Bückinga, H. Carbon availability triggers fungal nitrogen uptake and transport in arbuscular mycorrhizal symbiosis. Proc. Natl. Acad. Sci. USA 2012, 109, 2666-2671. [CrossRef]

30. Mauromicale, G.; Ierna, A.; Marchese, M. Chlorophyll fluorescence and chlorophyll content in field-grown potato as affected by nitrogen supply, genotype, and plant age. Photosynthetica 2006, 44, 76-82. [CrossRef]

31. Song, X.; Wang, Y.; Lv, X. Responses of plant biomass, photosynthesis and lipid peroxidation to warming and precipitation change in two dominant species (Stipa grandis and Leymus chinensis) from North China Grasslands. Ecol. Evol. 2016, 6, 1871-1882. [CrossRef] [PubMed]

32. Morales, M.; Munné-Bosch, S. Malondialdehyde: Facts and artifact. Plant Physiol. 2019, 1801, 246-251. [CrossRef] [PubMed]

33. Hodge, A.; Fitter, A.H. Substantial nitrogen acquisition by arbuscular mycorrhizal fungi from organic material has implications for N cycling. Proc. Natl. Acad. Sci. USA 2010, 107, 13754-13759. [CrossRef] [PubMed]

34. Chen, S.; Liao, W.; Liu, C.; Wen, Z.; Kincaid, R.L.; Harrison, J.H.; Elliott, D.C.; Brown, M.D.; Solana, A.E.; Stevens, D.J. Value-Added Chemicals from Animal Manure; Final Technical Report, Contract DE-AC06-76RL01830; US Department of Energy: Washington, DC, USA, 2003

35. Jin, H.R.; Liu, J.; Liu, J.; Huang, X. Forms of nitrogen uptake, translocation, and transfer via arbuscular mycorrhizal fungi: A review. Sci. China Life Sci. 2012, 55, 474-482. [CrossRef] [PubMed]

36. Bungau, S.; Behl, T.; Aleya, L.; Bourgeade, P.; Aloui-Sossé, B.; Purza, A.L.; Abid, A.; Samuel, A.D. Expatiating the impact of anthropogenic aspects and climatic factors on long-term soil monitoring and management. Environ. Sci. Pollut. Res. 2021, 28, 30528-30550. [CrossRef] [PubMed]

37. Qin, M.; Zhang, Q.; Pan, J.; Jiang, S.; Liu, Y.; Bahadur, A.; Peng, Z.; Yang, Y.; Feng, H. Effect of arbuscular mycorrhizal fungi on soil enzyme activity is coupled with increased plant biomass. Eur. J. Soil Sci. 2019, 71, 84-92. [CrossRef]

38. Samuel, A.D.; Bungau, S.; Tit, D.M.; Melinte, C.E.; Purza, L.; Badea, G.E. Effects of long-term application of organic and mineral fertilizers on soil enzymes. Rev. Chem. 2018, 69, 2608-2612. [CrossRef]

39. Samuel, A.D.; Tit, D.M.; Melinte, C.E.; Iovan, C.; Purza, L.; Gitea, M.; Bungau, S. Enzymological and physicochemical evaluation of the effects of soil management practices. Rev. Chim. 2017, 68, 2243-2247. [CrossRef]

40. Fang, F.; Wang, C.; Wu, F.; Tang, M.; Doughty, R. Arbuscular mycorrhizal fungi mitigate nitrogen leaching under poplar seedlings. Forests 2020, 11, 325. [CrossRef]

41. Wu, F.; Fang, F.; Wu, N.; Li, L.; Tang, M. Nitrate transporter gene expression and kinetics of nitrate uptake by Populus canadensis 'Neva' in relation to arbuscular mycorrhizal fungi and nitrogen availability. Front. Microbiol. 2020, 11, 176. [CrossRef]

42. Diouf, A.; Ndiaye, M.; Fall-Ndiaye, M.; Diop, T. Maize crop N uptake from organic material of Gliricidia sepium coinoculated with rhizobium and arbuscular mycorrhizal fungus in sub-Saharian africa sandy soil. Am. J. Plant Sci. 2017, 8, 428-440. [CrossRef]

43. Püschel, D.; Janoušková, M.; Voríšková, A.; Gryndlerová, H.; Vosátka, M.; Jansa, J. Arbuscular mycorrhiza stimulates biological nitrogen fixation in two Medicago spp. through improved phosphorus acquisition. Front. Plant Sci. 2017, 8, 390. [CrossRef] [PubMed]

44. Pitakdantham, R.; Suwanarit, A.; Suwanarit, P.; Leyval, C.; Sarobol, E.; Nopamornbodi, O.; Hoefner, W. Effects of arbuscular mycorrhizal fungal species (Glomus aggregatum and Acaulospora spinosa), nitrogen and phosphorus fertilizers on maize growth, root colonization and spore production. Thai J. Agric. Sci. 2004, 37, 173-180.

45. Karasawa, T.; Takebe, M.; Kasahara, Y. Arbuscular mycorrhizal (AM) effects on maize growth and AM colonization of roots under various soil moisture conditions. Soil Sci. Plant Nutr. 2000, 46, 61-67. [CrossRef]

46. Punyalue, A.; Jongjaidee, J.; Jamjod, S.; Rerkasem, B. Legume intercropping to reduce erosion, increase soil fertility and grain yield, and stop burning in highland maize production in Northern Thailand. CMU J. Nat. Sci. 2018, 17, 265-274. [CrossRef]

47. Lang, C.A. Simple micro determination of Kjeldahl nitrogen in biological materials. Anal. Chem. 1958, 30, 1692-1694. [CrossRef]

48. Shabala, S.N.; Shabala, S.I.; Martynenko, A.I.; Babourina, O.; Newman, I.A. Salinity effect on bioelectric activity growth, Na ${ }^{+}$ accumulation and chlorophyll fluorescence of maize leaves: A comparative survey and prospects for screening. Aust. J. Plant Physiol. 1998, 25, 609-616. [CrossRef] 
49. Jägerbrand, A.K.; Kudo, G. Short-term responses in maximum quantum yield of PSII $\left(\mathrm{F}_{\mathrm{V}} / \mathrm{F}_{\mathrm{m}}\right)$ to ex-situ temperature treatment of populations of bryophytes originating from different sites in Hokkaido, Northern Japan. Plants 2016, 5, 22. [CrossRef]

50. Maxwell, K.; Johnson, G.N. Chlorophyll fluorescence-a practical guide. J. Exp. Bot. 2000, 51, 659-668. [CrossRef]

51. Zhou, Y.; Lam, H.M.; Zhang, J. Inhibition of photosynthesis and energy dissipation induced by water and high light stresses in rice. J. Exp. Bot. 2007, 58, 1207-1217. [CrossRef] 